\title{
Partial Mole Coexistence with a Normal Live Fetus in Twin Pregnancy
}

DOI: https://doi.org/10.32007/med.1936/jfacmedbagdad.v60i4.10

Saabh I. Alkateeb*

Hala M. Alkhalidy**

\author{
CABMS RAD ,FIBMS-Rad, JBR, EDiR \\ FCS, DGO
}

J Fac Med Baghdad 2018; Vol.60, No.4 Received:Aug. 2018 Accepted: Dec. 2018 Published: May, 2019

This work is licensed under a Creative Commons Attribution-NonCommercial 4.0 International License.

\begin{abstract}
:
We present a case of dizygotic diamiontic twin pregnancy in which one fetus was normal with normal placenta, the 2nd fetus was normal appearing with partial molar placenta.

The patient was a 31-year-old presented to Central Private Hospital; her gestational age was 22 weeks +5 days following IVF (after 10 years of primary infertility) of diazygotic diamiontic twin pregnancy as a case of vaginal bleeding from 8 weeks of gestation with uterine contractions.

All required investigation and clinical assessments were carried out and revealing partial molar pregnancy in one fetus and normal placenta of the other one. Maternal BhCG was high for gestational age.

The patient had gestational DM \& hyperthyroidism. Appropriate treatment regarding her conditions was implemented

All appropriate management was implemented. The patient continued to bleed. Within few days of admission she had premature uncomplicated labor with normal vaginal delivery (gestational age was 23 Wks +3 days), both babies appeared normal, one placenta morphologically \&histologically typical of H.mole. The other one completely was normal.

Monitoring of serum BhCG and follow up transvaginal US was done until BhCG level returned to normal after 3 months of delivery without chemotherapy.

Close monitoring of pregnancy from early stages and discussing the possible complications to mother and baby (such as baby may be chromosomally abnormal \&may not survive) with parents is important to manage such complications.

It is also necessary to have post-natal close follow up for maternal BhCG levels to assess any possibility of invasive mole or choriocarcinoma.
\end{abstract}

\section{Introduction:}

Partial mole is a sub-type of H.mole which in turn falls under the spectrum of gestational trophoblastic disease [1]. The partial hydatidiform mole is usually triploid (one maternal and two paternal haploid sets), either from dispermic fertilization or from fertilization with an unreduced diploid sperm. There is usually a fetus and a large placenta. The fetus usually dies within a few weeks of conception. Very rarely, a partial molar pregnancy is digynic (two maternal and one paternal haploid set). In these cases, the placenta is small, the villi show minimal hydropic changes, and the fetus is growth-restricted. Some of these pregnancies resulted in live births, with subsequent early neonatal death [2]. We present a case of dizygotic, diamiontic twin pregnancy in which one fetus was normal with normal placenta, and the other fetus normal

\begin{tabular}{lrr}
\hline * Central Private & $\begin{array}{l}\text { Hospital } \\
\text { Author }\end{array}$ & $\begin{array}{r}\text { Sharjah-UAE } \\
\text { Corresponding }\end{array}$ \\
$\begin{array}{l}\text { sabaalkhateeb@yahoo.com } \\
\text { **Central Private Hospital }\end{array}$ & Sharjah-UAE \\
halaalkhalidy@yahoo.com &
\end{tabular}

appearing with partial molar placenta.Incidence of normal fetus \& partial molar placenta is 0.005 $0.01 \%$ of all pregnancies [3], [4]. The percentage of twins with one molar pregnancy is expected to increase with proper treatment for infertility and early diagnosis with ultrasound [5].

\section{Case Report:}

The Patient was 31 years old when she presented to Central Private Hospital, her gestational age was 22 weeks +5 days with IVF (after 10 years of primary infertility) of diazygotic diamiontic twin pregnancy as a case of vaginal bleeding from 8 -week gestation with uterine contractions.

Ultrasound revealed first fetus with no fetal structural abnormalities (no evidence of growth retardation or gross congenital anomalies) \& normal fetal biometry with partially (one half) cystic placenta \&other half was normal placenta.

Another fetus was completely normal with normal placenta.

Maternal BhCG was 109467 MIU/ml. 
The patient had gestational DM \&thyroid dysfunction.

Investigations included thyroid function test, thyroid antibodies, oral glucose tolerance test and thyroid gland ultrasound.

The patient had gestational DM controlled by diet \&Metformin tablet (1000mg twice) monitored by glucose chart, she also had hyperthyroidism which controlled well with physician by Carbimazole tablet (5mg 3 times) with Propranolol tablet (10mg twice) All required management was given to patient appropriately including management for uterine contractions (Progesterone suppositories/twice daily $\&$ Progesterone tablet /10mg twice daily)

All appropriate management was implemented, although, patient still had bleeding. A few days after admission she had premature labor with normal uncomplicated vaginal delivery at gestational age $23 \mathrm{WKs}+3$ days, both babies appeared normal (fist one weighs $375 \mathrm{gm} \&$ second one weighs $400 \mathrm{gm}$ ), one placenta morphologically and histologically typical of $\mathrm{H}$. mole, other one completely normal.

Serum titer of BhCG of mother decreased to 203 within one month of delivery without chemotherapy. 10 days after delivery, follow up transvaginal US revealed irregular vascular thickening of endometrium (this may indicate persistence trophoblastic disease of pregnancy/choriocarcinoma) Serum BhCG returned to normal level after 3 months of delivery without chemotherapy.
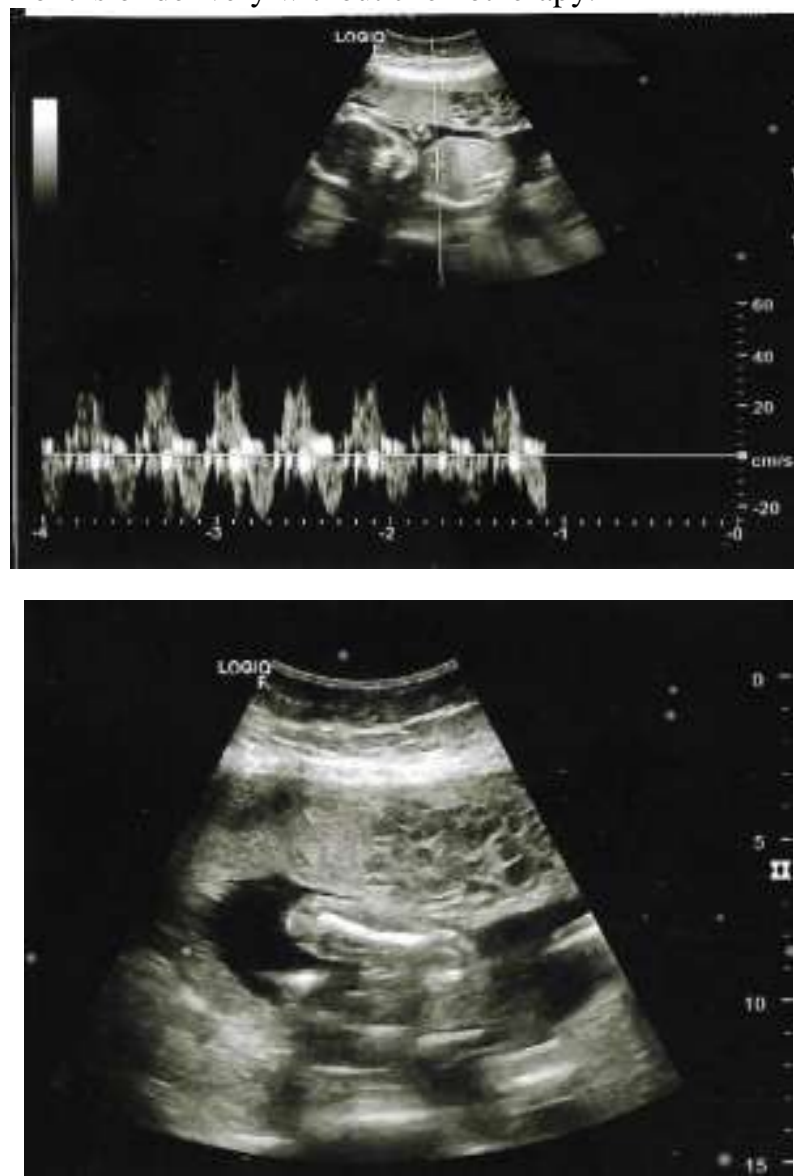

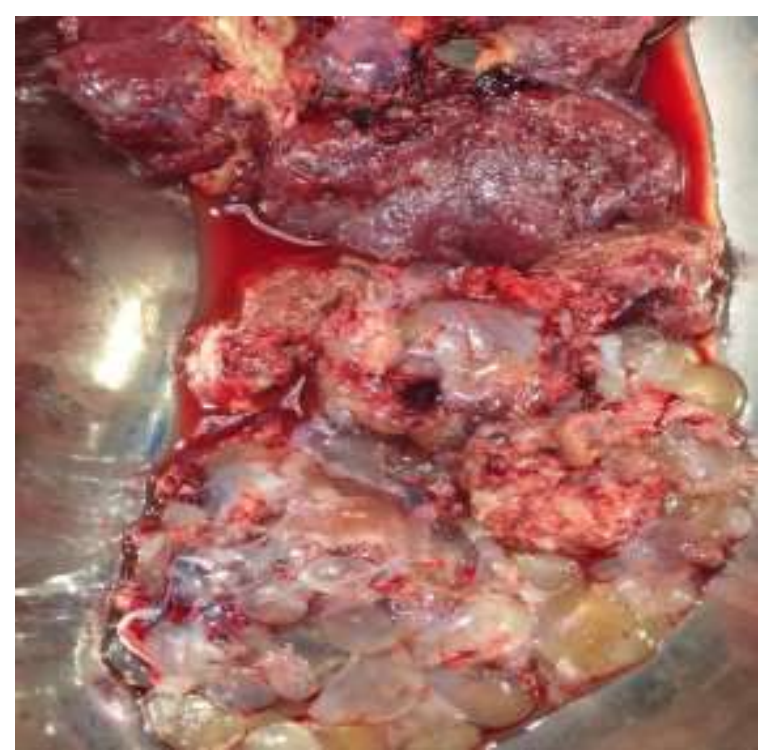

\section{Discussion:}

There are three types of Hydatidiform mole with coexistent normal fetus. First type is a twin pregnancy with one normal fetus (normal placenta) and another complete mole; the second is a twin pregnancy with one normal fetus (normal placenta) and another partial mole as in our case; and the third is a singleton normal fetus with partial molar placenta [6].

Presence of medical complication with very high $\mathrm{S} \beta$ hCG (> $106 \mathrm{IU} / \mathrm{L}$ ) portend a poor outcome and suggestive of aggressive trophoblastic growth, it serves as an indication for the termination of pregnancy in such cases [7].

Many authors reported cases of partial molar pregnancy with live fetus; Lavaya RAI et al reported a case of live fetus in twin pregnancy with Hydatidiform mole [8].

Management of molar changes associated with normal appearing fetus still remains challenging. The serum B hCG level can be used as a marker, if serum B hCG level is greater than $106 \mathrm{mIU} / \mathrm{mL}$, termination of pregnancy is recommended [9].

In our case all required investigations and clinical assessments were done during the pregnancy \&after labour.

Our patient had gestational DM controlled by diet \&Metformin tablet followed by glucose chart, she also had hyperthyroidism which controlled well with physician by Carbamazole tablet with Propranalol tablet

All required management were given to patient appropriately including management for uterine contractions (Progesterone suppositories \&Progestrone tablet)

Serial measurements of BhCG \&follow up with transvaginal US after labour were done until BhCG returned to normal value after 3months of labour, this indicates patient had no persistent gestational trophoblastic disease \&didn't need chemotherapy 


\section{References}

1. Dr. Rohit Sharma, Dr.Yuranga Weerakkody et al, Partial hydatidiform mole,radiopedia; https://radiopaedia.org/articles/partial-

hydatidiform-mole.

2. Cavaliere A, Ermito $S$, Dinatale A, Pedata $R$. Management of molar pregnancy. Journal of prenatal medicine. 2009 Jan;3(1):15.

3. Agarwal $R$, Agarwal $S$, Roy KK, Kumar $S$. Diploid partial mole with neonatal survival--a case report. Indian journal of pathology \& microbiology. 2005 Apr;48(2):225-7.

4. Albers E, Daneshmand S, Hull A. Complete Hydatidiform Coexistent Term Twin Pregnancy. Journal of Perinatology. 2001 Feb;21(1):72.

5. Lavanya RA, Shripad H, Guruvare S, Prashanth A, Mundkur A. Twin pregnancy with Hydatidiform Mole and Co-existent Live Fetus: Lessons Learnt. The Malaysian journal of medical sciences: MJMS. 2014 Nov;21(6):61.

6. Shazly SA, Ali MK, Badee AY, Alsokkary AB, Khodary MM, Mostafa NA. Twin pregnancy with complete hydatidiform mole and coexisting fetus following ovulation induction with a non-prescribed clomiphene citrate regimen: a case report. Journal of medical case reports. 2012 Dec;6(1):95.
7. Bristow RE, Shumway JB, Khouzami AN,Witter FR. Complete hydatidiform mole and surviving coexistent twin. Obstetrical \&gynecological survey. 1996 Dec 1;51(12):705-9.

8. Lavanya RA, Shripad H, Guruvare S, Prashanth A, Mundkur A. Twin pregnancy with Hydatidiform Mole and Co-existent Live Fetus: Lessons Learnt. The Malaysian journal of medical sciences: MJMS. 2014 Nov;21(6):61.

9. Rahamni M, Parviz S. A case report of partial molar pregnancy associated with a normal appearing dizygotic fetus. Asian Pacific Journal of Reproduction. 2016 Apr 1;5(2):171-3. 


\section{الحمل العنقودي الجزئي مع جنين غير مشوه في حالة التوأم}

\section{د. د. ديأ اسماعيل نبيل \\ د. دالة محمد الديل}

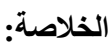

نقدم حالة من الحمل التُّة التو أم ثنائي الكيس ثنائي الجنين حيث يكون احد الاجنة طبيعيًا مع المشيمة الطبيعية ، ويكون الجنين الآخر طبيعيًا مع المشيمة

العنقودية الجزئية.

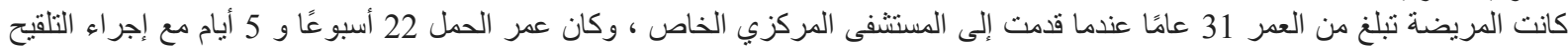

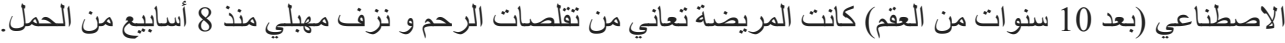

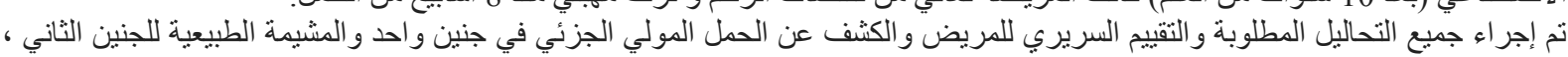

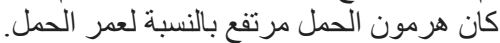

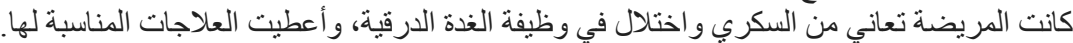

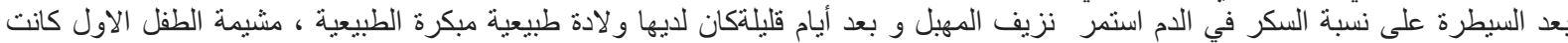
عنقودية جزئية ، و وأخرى طبية فيعية تمامبا.

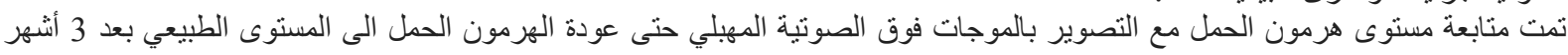
بدون علاج كيميائي. لذا فإن المر اقبة الدقيقة للحمل من المر احل المبكرة ومناقثة المضاعفات المبات المحتملة للأم والطفل مع الو الدين أمر مهم لمنع مثل هذه المضاعفات.

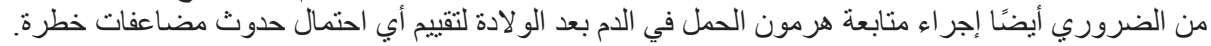

